\title{
Mar sem água
}

\author{
Rosana CARVALHO PAIVA ${ }^{1}$ \\ 1 Universidade Federal da Amazonas. Manaus, AM, Brasil.
}

Jura que não nos vê passar?

entregaram a esperança

na entrada do teu mar

mas você é mar sem água

mar sem ressaca, mar sem vaga

de santa realeza

de rei da alforria

de terroristacolonial

de fascista hipocrisia

de império limitado

de liberdade esmaecida

Rodamos na festa cigana

com roda de vento

agora a sina será atravessar

teu reino de miragem

só areia pra passar

mar sem água, mar sem vaga

Torres, tronos, fuzis

armas e papeis

palavras e cargos

elogios e escárnios

peões armados nos campos de areia

que o vento desmanchará 
Jura que não nos vê passar?

Sulcando o caminho com roda de vento

porque um dia alguém esperou

chegar a ser

a ter

a tranquilidade

daquele pastor

que tange o rebanho compassadamente

por paragens de uma via láctea celestial

do qual nos falaram um dia

e que nos fará perder sete anos buscando

sete anos atravessando

um mar sem água

Recebido: 01 de novembro de 2018

Aceito: 18 de dezembro de 2018

Rosana Carvalho Paiva

Doutoranda em Antropologia pelo Programa de Pós-Graduação em Antropologia Social - UFAM.

Mestre em Antropologia pelo PPGA - UFBA. Pesquisa sobre violência, ameaçados de morte, conflitos territoriais

e terror de Estado.

(D) http://orcid.org/0000-0002-1031-1318

<carvalhorosana8@gmail.com> 